\title{
SENSITIVITY OF MENINGOCOCCI TO SODIUM SULPHADIAZINE AND SIX ANTIBIOTICS
}

\author{
J. D. Abbott, D. Adams and T. J. Collins \\ Public Health Laboratory, Withington Hospital, Manchester
}

THERE have been many reports of the emergence of sulphonamide-resistant meningococci in the USA since the outbreak in 1963 of meningitis due to these organisms at a naval training centre in San Diego (Millar et al., 1963). We report the results of sensitivity tests on 170 strains isolated in the UK from 1966 to 1968.

\section{MATERIALS AND METHODS}

Eighty-two strains were isolated from cerebrospinal fluid (CSF) and 6 from blood culture. Of these 88 strains, 23 were from the Manchester conurbation and 65 from other areas: 4 from Aberdeen, 20 from Belfast, 6 from Birmingham, 13 from Coventry, 6 from London, 1 from Middlesbrough, 1 from Middlesex, 1 from Plymouth, 5 from Portsmouth, 2 from Southampton, 2 from Stafford, 2 from Sussex and in 2 the source was unknown. There were 72 strains isolated from postnasal swabs, 7 from sputa, 2 from eye swabs and 1 from a vaginal swab. Of these 82 strains, 10 were from Southampton and the rest from the Manchester conurbation.

\section{Confirmation of identity of meningococci}

All strains were Gram-negative diplococci, oxidase positive, growing on blood agar at $36^{\circ} \mathrm{C}$ in a candle jar with typical colonial morphology, and showing no growth, or rarely slight growth, on blood agar after overnight incubation at $22^{\circ} \mathrm{C}$. On 10 per cent. hydrocele agar slopes with 1 per cent. added carbohydrate, most strains attacked glucose and maltose, but not sucrose; occasional strains attacked glucose or maltose slowly or not at all. Cultures were preserved for day to day use on Dorset's egg slopes in $\frac{1}{4} \mathrm{Oz}$. $(5 \mathrm{ml})$ screw-capped bottles at $30^{\circ} \mathrm{C}$, and subcultured about every $3-4 \mathrm{mth}$. A proportion of strains were preserved by freeze-drying.

\section{Serological typing}

All strains were tested as suspensions of organisms heated at $100^{\circ} \mathrm{C}$ for $30 \mathrm{~min}$. against group $\mathrm{A}, \mathrm{B}$ and $\mathrm{C}$ sera by tube agglutination tests incubated overnight at $50^{\circ} \mathrm{C}$.

One group-A serum, two group-B sera and one group-C serum were used. The strains for making the group-A serum, one of the group-B sera, and the group-C serum were obtained from Dr K. W. Slaterus (University of Amsterdam). Another group-B strain obtained from Dr C. M. Patricia Bradstreet (Standards Laboratory for Serological Reagents, Colindale) was used to prepare the second group-B serum.

\section{Sensitivity tests}

All drugs were kept at $4^{\circ} \mathrm{C}$ in a tightly sealed container with a desiccant. Dilutions were made in sterile, distilled water from the freshly weighed out powder and used on the day of the test. The drugs used were sodium sulphadiazine (May and Baker), benzylpenicillin (Glaxo Laboratories, 1665 IU per mg), ampicillin (Beecham Research Laboratories,

Received 28 May 1969; revised MS accepted 23 Sept. 1969.

J. MED. MICROBIOL,-VOL. 3 (1970) 
$840 \mu \mathrm{g}$ per $\mathrm{mg}$ ), erythromycin (Eli Lilly “ Ilotycin "), tetracycline hydrochloride (Pfizer, $984 \mu \mathrm{g}$ per mg), chloramphenicol (Parke Davis), and cephaloridine (Glaxo Laboratories). Because of the low solubility of erythromycin in water the initial solution was made in methanol and not in distilled water.

\section{Sulphonamide sensitivity}

One millilitre of the appropriate dilution of sodium sulphadiazine was added to $19 \mathrm{ml}$ of Bacto Mueller-Hinton medium (Difco Laboratories) at $50^{\circ} \mathrm{C}$ and plates were poured in plastic petri dishes.

\section{Antibiotic sensitivity}

One millilitre of the appropriate dilution of antibiotic and $1 \mathrm{ml}$ of defibrinated horse blood were added to $18 \mathrm{ml}$ of Oxoid blood agar base no. $2 \mathrm{CM} 271$ at $50^{\circ} \mathrm{C}$ and plates were poured as above.

Cultures for testing were grown for 1 day on blood agar plates in a candle jar and then inoculated into $2 \mathrm{ml}$ of 10 per cent. horse serum in Oxoid nutrient broth no. 2 CM67 in

\section{TABLE I}

Sensitivity of 170 strains of meningococci to sodium sulphadiazine

\begin{tabular}{|c|c|c|c|c|c|c|c|c|c|c|c|c|}
\hline \multirow{2}{*}{ Source } & \multicolumn{11}{|c|}{$\begin{array}{l}\text { Number of strains inhibited by sodium sulphadiazine } \\
(\mu \mathrm{g} \text { per } \mathrm{ml})\end{array}$} & \multirow{2}{*}{$\begin{array}{c}\text { Total } \\
\text { number of } \\
\text { strains }\end{array}$} \\
\hline & $<0.1$ & $0 \cdot 1$ & $0 \cdot 2$ & 0.4 & 0.8 & $1 \cdot 6$ & $3 \cdot 2$ & $6 \cdot 4$ & 10 & 50 & 100 & \\
\hline CSF . & 1 & 0 & 8 & 38 & 21 & 14 & 1 & 2 & 1 & 1 & 1 & 88 \\
\hline $\begin{array}{l}\text { Postnasal swabs } \\
\text { and other }\end{array}$ & 0 & 4 & 12 & 28 & 23 & 12 & 1 & 0 & 1 & 1 & 0 & 82 \\
\hline
\end{tabular}

$\frac{1}{4} \mathrm{oz} .(5 \mathrm{ml})$ screw-capped bottles; these were incubated with caps loose at $36^{\circ} \mathrm{C}$ in a candle jar overnight. The following morning they were removed from the candle jar, but kept at $36^{\circ} \mathrm{C}$ until ready for use. The serum-broth cultures usually showed uniform turbidity on gentle shaking, though occasional strains, particularly those from postnasal swabs, yielded granular growth. Before use, the serum-broth culture was diluted about 1 in 150 in Oxoid nutrient broth no. 2 CM67 and this dilution was inoculated on the dried plates containing sulphadiazine or antibiotics with a phage applicator (Tarr, 1958). The inoculum contained between 1000 and 10,000 organisms. The plates were incubated at $36^{\circ} \mathrm{C}$ in candle jars and the results were recorded after 1 and 2 days' incubation. The plates were examined by naked eye, and inhibition was recorded where there was no growth, or fewer than 10 colonies; faint growth seen with a $\times 8$ lens but not by naked eye was ignored. When sulphonamideresistant strains were found the sensitivity tests to sulphadiazine were repeated with an inoculum of about $500-2000$ organisms. The inoculum was put on by hand with a nichrome wire loop of about $1.0-1.5 \mathrm{~mm}$ internal diameter. This facilitated the reading by yielding a clear-cut end-point.

\section{RESULTS}

We found in general that it was preferable to read the plates after 2 days' incubation, as occasional strains grow poorly in 1 day; the minimum inhibitory 


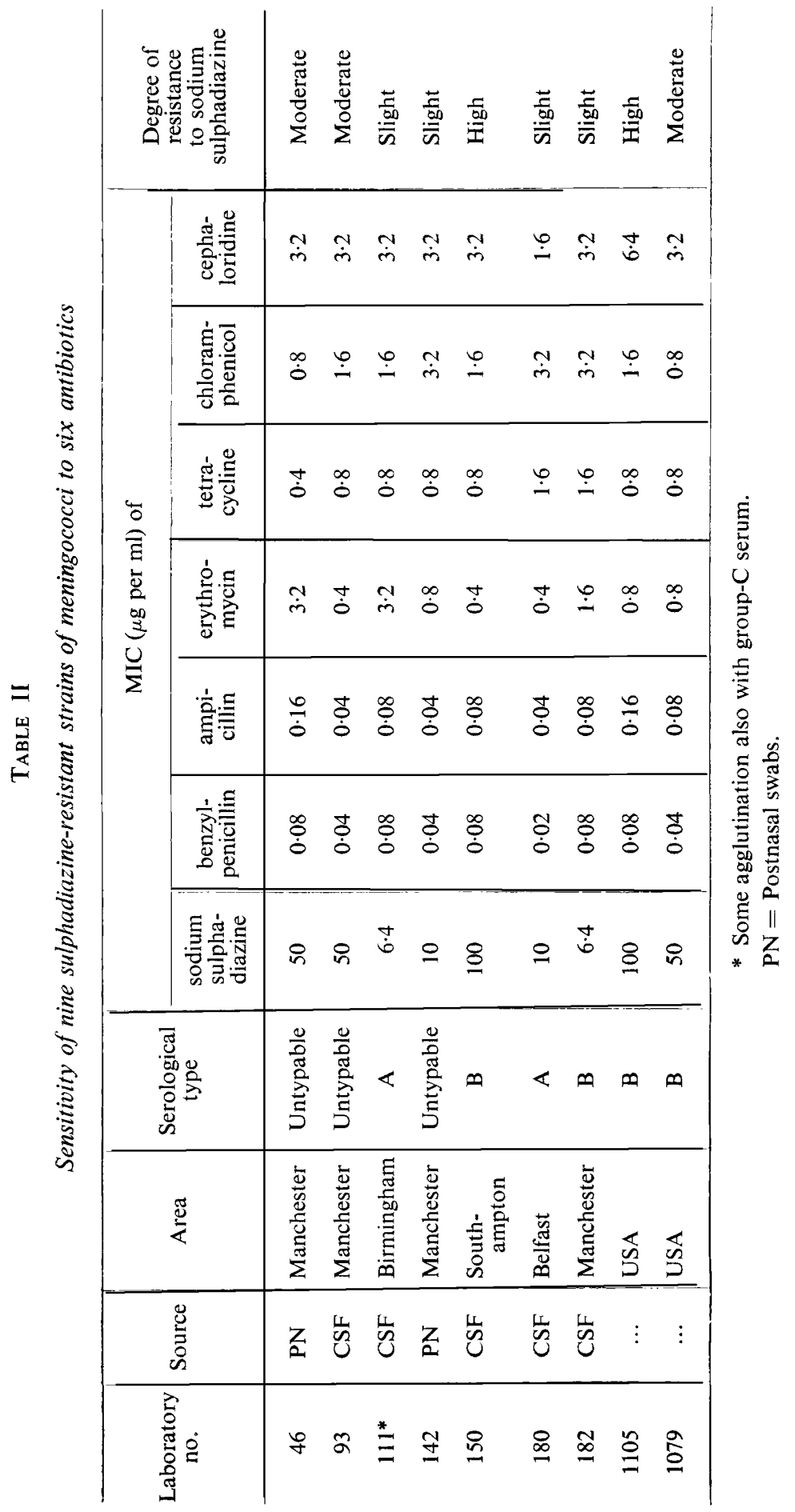


concentrations (MIC) given in the text and tables therefore refer to results after 2 days' incubation.

All 170 strains were tested with sodium sulphadiazine (table I). One hundred and sixty-one out of 170 (95 per cent.) were inhibited by $1.6 \mu \mathrm{g}$ per $\mathrm{ml}$,

TABLE III

Sensitivity of 116 strains of meningococci to 6 antibiotics

\begin{tabular}{|c|c|c|c|c|c|c|c|c|}
\hline \multirow{2}{*}{ Source } & \multirow{2}{*}{ Antibiotic } & \multicolumn{7}{|c|}{$\begin{array}{c}\text { Number of strains inhibited by antibiotic at } \\
\text { concentration }(\mu \mathrm{g} \text { per } \mathrm{ml})\end{array}$} \\
\hline & & $<0.02$ & & 02 & 0.04 & 0.08 & & $0 \cdot 16$ \\
\hline $\begin{array}{l}\text { CSF. } \\
\text { Postnasal swabs and other }\end{array}$ & Benzyl-penicillin & $\left\{\begin{array}{l}2 \\
0\end{array}\right.$ & & 5 & $\begin{array}{l}26 \\
32\end{array}$ & $\begin{array}{l}21 \\
24\end{array}$ & & $\begin{array}{l}2 \\
1\end{array}$ \\
\hline $\begin{array}{l}\text { CSF } \\
\text { Postnasal swabs and other }\end{array}$ & Ampicillin & $\left\{\begin{array}{l}0 \\
0\end{array}\right.$ & & 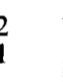 & $\begin{array}{l}20 \\
12\end{array}$ & $\begin{array}{l}31 \\
31\end{array}$ & & $\begin{array}{r}4 \\
15\end{array}$ \\
\hline \multirow{2}{*}{ Source } & \multirow{2}{*}{ Antibiotic } & \multicolumn{7}{|c|}{$\begin{array}{l}\text { Number of strains inhibited by antibiotic at } \\
\text { concentration }(\mu \mathrm{g} \text { per } \mathrm{ml})\end{array}$} \\
\hline & & $<0 \cdot 2$ & 0.2 & 0.4 & $0 \cdot 8$ & 1.6 & $3 \cdot 2$ & $6 \cdot 4$ \\
\hline $\begin{array}{l}\text { CSF. } \\
\text { Postnasal swabs and other }\end{array}$ & Erythromycin & $\left\{\begin{array}{l}4 \\
0\end{array}\right.$ & $\begin{array}{l}0 \\
0\end{array}$ & $\begin{array}{l}19 \\
11\end{array}$ & $\begin{array}{l}26 \\
29\end{array}$ & $\begin{array}{l}6 \\
5\end{array}$ & $\begin{array}{r}2 \\
14\end{array}$ & $\begin{array}{l}0 \\
0\end{array}$ \\
\hline $\begin{array}{l}\text { CSF. } \\
\text { Postnasal swabs and other }\end{array}$ & Tetracycline & $\left\{\begin{array}{l}0 \\
0\end{array}\right.$ & $\begin{array}{l}0 \\
0\end{array}$ & $\begin{array}{r}7 \\
13\end{array}$ & $\begin{array}{l}39 \\
28\end{array}$ & $\begin{array}{l}10 \\
18\end{array}$ & $\begin{array}{l}1 \\
0\end{array}$ & $\begin{array}{l}0 \\
0\end{array}$ \\
\hline $\begin{array}{l}\text { CSF. } \\
\text { Postnasal swabs and other }\end{array}$ & Chloramphenicol & $\left\{\begin{array}{l}0 \\
0\end{array}\right.$ & $\begin{array}{l}0 \\
0\end{array}$ & $\begin{array}{l}0 \\
0\end{array}$ & $\begin{array}{r}9 \\
14\end{array}$ & $\begin{array}{l}43 \\
45\end{array}$ & $\begin{array}{l}5 \\
0\end{array}$ & $\begin{array}{l}0 \\
0\end{array}$ \\
\hline $\left.\begin{array}{l}\text { CSF . } \\
\text { Postnasal swabs and other }\end{array}\right\}$ & Cephaloridine & $\left\{\begin{array}{l}0 \\
0\end{array}\right.$ & $\begin{array}{l}0 \\
0\end{array}$ & $\stackrel{0}{0}$ & $\begin{array}{l}0 \\
1\end{array}$ & $\begin{array}{r}10 \\
7\end{array}$ & $\begin{array}{l}46 \\
45\end{array}$ & $\begin{array}{l}1 \\
6\end{array}$ \\
\hline
\end{tabular}

but two strains required $3 \cdot 2 \mu \mathrm{g}$ per $\mathrm{ml}$; all these strains have been classed as sensitive. Seven strains-no. 46, 93, 111, 142, 150, 180 and 182--showed increased resistance to sodium sulphadiazine. We have arbitrarily classed as " slightly resistant" strains with MIC of 6.4 and $10 \mu \mathrm{g}$ per ml, " moderately resistant" with MIC of $50 \mu \mathrm{g}$ per ml, and "highly resistant" with MIC of $100 \mu \mathrm{g}$ per $\mathrm{ml}$ or more. Further details on these seven strains are given in table II, together with the results of two strains-no. 1105 and 1079-kindly supplied by Dr Harry A. Feldman of the State University of New York. Five of the seven resistant strains were grown from cerebrospinal fluid (CSF) and two from postnasal swabs. Four of the strains showed slight resistance, two 
were moderately resistant, and one strain from CSF was highly resistant. Two of the resistant strains, including the one highly resistant strain, were group B and so were the two resistant strains from the USA. One strain showing slight resistance was group $\mathrm{A}$ and another slightly resistant strain agglutinated with both the type- $A$ and type- $C$ sera; the remaining three strains were untypable. Resistant strains were not confined to cultures from one area.

Tests for sensitivity to antibiotics were carried out on the first 112 strains investigated, which included three sulphadiazine-resistant strains (no. 46, 93 and 111). Since there was no evidence of resistance to the antibiotics tested, further tests were carried out only on the sulphadiazine-resistant strains. The results of the sensitivity tests to six antibiotics are shown in table III.

Over half of the strains were inhibited by $0.04 \mu \mathrm{g}$ benzyl-penicillin per $\mathrm{ml}$, and over 97 per cent. by $0.08 \mu \mathrm{g}$ per $\mathrm{ml}$; a third of the strains were inhibited by $0.04 \mu \mathrm{g}$ of ampicillin per $\mathrm{ml}, 84$ per cent. by $0.08 \mu \mathrm{g}$ per $\mathrm{ml}$ and the remainder by

TABLE IV

Serological typing of 170 strains of meningococci

\begin{tabular}{|c|c|c|c|c|c|}
\hline Source & Group A & Group B & Untypable & Not tested & Total \\
\hline Cases of clinical infection* & 10 & 32 & 44 & 2 & 88 \\
\hline Postnasal swabs and other & 5 & 19 & 50 & 8 & 82 \\
\hline
\end{tabular}

* Six strains from blood culture and 82 from CSF.

$0.16 \mu \mathrm{g}$ per $\mathrm{ml}$. Three-quarters of the strains were inhibited by $0.8 \mu \mathrm{g}$ of erythromycin or tetracycline per $\mathrm{ml}$, the remainder by $3.2 \mu \mathrm{g}$ of erythromycin per $\mathrm{ml}$, and all but one by $1.6 \mu \mathrm{g}$ of tetracycline per $\mathrm{ml}$. About 20 per cent. of the strains were inhibited by $0.8 \mu \mathrm{g}$ chloramphenicol per $\mathrm{ml}, 94$ per cent. by $1.6 \mu \mathrm{g}$ per $\mathrm{ml}$ and the rest by $3.2 \mu \mathrm{g}$ per $\mathrm{ml}$; about 15 per cent. were inhibited by $1.6 \mu \mathrm{g}$ cephaloridine per $\mathrm{ml}$, over 90 per cent. by $3.2 \mu \mathrm{g}$ per $\mathrm{ml}$ and the remainder by $6.4 \mu \mathrm{g}$ per $\mathrm{ml}$. The sensitivity to antibiotics of the seven sulphadiazine-resistant strains and of the two strains from the USA are shown in table II. There is no evidence of increased resistance to any of the antibiotics tested.

The results of serological typing are shown in table IV: 9 per cent. of the strains were group A, 32 per cent. were group B, and 59 per cent. were untypable with group A and B sera. A rather higher proportion of strains from CSF or blood were typable ( 42 out of $86=49$ per cent.), compared with strains from nasopharynx and other sites ( 24 out of $74=32$ per cent.).

\section{DISCUSSION}

Interest in the clinical aspects of sulphadiazine-resistant strains followed the report in 1963 of the outbreak of meningococcal infection amongst recruits at 
the San Diego Naval Training Centre (Millar et al., 1963), in which sulphonamide prophylaxis failed. In another report from California, Leedom et al. (1965) found that 35 of 106 strains (33 per cent.) of meningococci isolated from civilians with meningococcal disease had an MIC of $100 \mu \mathrm{g}$ or more per ml to sulphadiazine. Feldman (1965) tested over 500 strains from the USA, Western Europe and Africa, from both civilian and military sources: resistance was detected amongst group-B strains and to a lesser extent in group-C strains submitted from both the USA and Europe. Wiggins and Schubert (1967) at the Communicable Disease Center, Atlanta, Georgia, examined over 1600 cultures isolated from 1964 to 1966, using as their criterion of resistance growth in a medium containing $10 \mu \mathrm{g}$ of sulphadiazine per $\mathrm{ml}$. The resistance rate ranged from 28 per cent. in 1964, to 31 per cent. in 1965 and 39 per cent. in 1966. There have been many other reports of sulphonamide-resistant meningococci from the USA (Gauld et al., 1965; Eickhoff and Finland, 1965; Ivler et al., 1965; Farrell and Dahl, 1966). In Great Britain, Fallon and Brown (1966) examined ten cultures of which nine were fully sensitive to sulphadiazine and one showed scanty growth at a level of $10 \mu \mathrm{g}$ per ml.

In the present survey of 170 strains isolated in the United Kingdom one was highly resistant (MIC $100 \mu \mathrm{g}$ per $\mathrm{ml}$ ) to sulphadiazine, two were moderately resistant (MIC $50 \mu \mathrm{g}$ per ml) and four slightly resistant (MIC 6.4-10 $\mu \mathrm{g}$ per $\mathrm{ml}$ ). Any classification of resistance, particularly to sulphonamides, depends upon the technique used, e.g., the medium, the time of incubation and the size of the inoculum. Leedom et al. classified strains of meningococci inhibited by $1-5 \mu \mathrm{g}$ sulphadiazine per $\mathrm{ml}$ as sensitive, those with MIC of 10,20 and $50 \mu \mathrm{g}$ per ml as intermediate, and those with MIC of $100 \mu \mathrm{g}$ per ml or more as resistant. These workers, however, used an inoculum of $10^{5}-10^{6}$ organisms, whilst the end-point of our resistant strains is based upon an inoculum of about 500-2000 organisms.

Certain implications arise from the presence of sulphonamide-resistant meningococci. According to reports from the US Army, quoted by Brown and Condit (1965), organisms resistant to $1 \mu \mathrm{g}$ per $\mathrm{ml}$ or more cannot be eradicated from the nasopharynx of carriers with standard courses of sulphadiazine. Although other drugs--penicillins and tetracyclines--suppress the carriage of meningococci during treatment, it is the experience of several workers (Bristow, Van Peenan and Volk, 1965; Leedom et al.; Dowd et al., 1966) that carrier rates revert to normal when the drugs are stopped. Ivler et al. point out that there is an immediate need for a prophylactic agent for use in treating nasopharyngeal carriers in high-risk groups, such as military recruits or household contacts of patients. According to Leedom et al., meningococci with an MIC of more than $50 \mu \mathrm{g}$ per $\mathrm{ml}$ could be expected to produce disease that is clinically resistant to sulphonamides. Maximum serum levels of sulphadiazine with normal doses of sulphadiazine are about $100 \mu \mathrm{g}$ per $\mathrm{ml}$ and CSF levels are about 67-80 per cent. of the serum levels. The outstanding advantage of sulphonamides for treating meningococcal disease is the free diffusibility into cerebrospinal fluid, but benzyl-penicillin or ampicillin given in large enough doses also penetrate in adequate concentration when the meninges are acutely inflamed (Br. Med. J., 
1966). Workers in the USA agree that at the present time sulphonamide-resistant meningococci are sensitive to other antibiotics-benzyl-penicillin, ampicillin, chloramphenicol and tetracycline (Ivler et al.). In our own series, of 116 strains tested all were sensitive in vitro to these antibiotics. Feldman advises treatment with massive doses of penicillin $G$, and if sulphonamides are used he recommends that they should be a secondary rather than the primary drug. Mathies et al. (1965) had good results in the treatment of meningococcal meningitis with ampicillin: of 56 patients treated with ampicillin three died ( 5 per cent.), and of 77 patients treated with penicillin seven died ( 9 per cent.). Until recently sulphadiazine was the drug of choice in the UK, but according to Garrod and O'Grady (1968) treatment with penicillin in addition to sulphonamides is now the practice. Benzyl-penicillin or ampicillin must be given in large doses parenterally-by the intravenous or intramuscular route-and there is still a reasonable case for giving sulphonamides as well, since in our present series of 88 strains from CSF and blood, only one strain showed a high level of resistance to sulphonamides.

McKenzie et al. (1967) comment on ten patients with meningococcal meningitis treated with cephaloridine by intramuscular and intrathecal injection that it was their " strong clinical impression that patients with meningococcal meningitis were slower to respond than patients treated conventionally". The majority of our strains required $3 \cdot 2 \mu \mathrm{g}$ of cephaloridine per $\mathrm{ml}$ to inhibit growth compared with an MIC of $0 \cdot 12-1 \cdot 0 \mu \mathrm{g}$ per ml quoted by Garrod and O'Grady. In the series reported by McKenzie et al. the levels of cephaloridine in the cerebrospinal fluid $24 \mathrm{hr}$ after intrathecal injection were below our MIC in over half the cases. By contrast, Dr A. G. Ironside tells us that he found that in a series of cases treated with the standard dosage of 2 mega units of benzyl-penicillin, irrespective of age, 4 hourly, by intramuscular injection, the penicillin level in the cerebrospinal fluid exceeded the MIC in 17 of 18 cases.

Chloramphenicol has been used effectively in the treatment of meningococcal meningitis (Florey, 1957) and is an alternative treatment for patients allergic to penicillin.

Erythromycin and tetracycline have been used in attempts to reduce the carrier state of sulphadiazine-resistant meningococci (Dowd et al.).

The distribution of serological types appears to be different in this country from that in the USA. In a series from California examined by Ivler et al. there were 126 strains from the CSF and blood, and 188 from the pharynx: of these 0.9 per cent. were group A, 70.4 per cent. group B, 13.4 per cent. group C and $15 \cdot 3$ per cent. untypable. By comparison in our series of 160 cultures tested, 9 per cent. were group A, 32 per cent. group B and 59 per cent. untypable. Most of the sulphonamide-resistant strains isolated in the USA and Europe were group B, although some were group $\mathrm{C}$ (Feldman). The one highly resistant strain in our series was group B and the two strains agglutinating with group-A sera showed low levels of resistance only.

It would be prudent to continue to monitor strains of meningococci isolated in this country for sensitivity to sulphonamides and antibiotics in order to detect changes in sensitivity. 


\section{SUMMARY}

One hundred and seventy strains of meningococci isolated in the UK from 1966 to 1968 were tested for sensitivity to sodium sulphadiazine. Eighty-eight strains were isolated from CSF or blood and 82 strains from postnasal swabs and other sources. Seven strains were resistant to sulphonamides: one was highly resistant (MIC $100 \mu \mathrm{g}$ per $\mathrm{ml}$ ), two were moderately resistant (MIC $50 \mu \mathrm{g}$ per $\mathrm{ml}$ ) and four were slightly resistant (MIC 6.4 or $10 \mu \mathrm{g}$ per $\mathrm{ml}$ ). One hundred and sixteen strains, including the seven sulphonamide-resistant strains, were tested for sensitivity to six antibiotics: benzyl-penicillin, ampicillin, erythromycin, tetracycline, chloramphenicol and cephaloridine. None of the strains showed any increase in resistance to these antibiotics.

One hundred and sixty strains were typed serologically: 15 (9 per cent.) were group A, 51 (32 per cent.) were group B and 94 (59 per cent.) were untypable.

We thank Dr K. W. Slaterus for providing us with prototype strains of group A, B and C; Dr Harry A. Feldman for the two sulphonamide-resistant strains; and the many pathologists in the UK who so kindly provided current strains of meningococci. We are most grateful to Dr C. M. Patricia Bradstreet and Miss A. J. Tannahill, Standards Laboratory for Serological Reagents, Colindale, for advice in the preparation and use of meningococcal sera and for generous supplies of their own sera; also to Dr M. T. Parker, Chairman of the Public Health Laboratory Service Steering Committee on Antibiotic Resistance of Pathogens, and Dr A. G. Ironside, Clinical Director, Department of Infectious Diseases, Monsall Hospital, for their help and encouragement.

\section{REFERENCES}

Bristow, W. M., Van Peenan, P. F. D., 1965. Amer. J. Publ. Hlth, 55, 1039. AND VOLK, $\mathbf{R}$.

British Medical Journal (Leading 1966. Br. Med.J., 1, 1253.

ARTICLE)

Brown, J. W., AND Condrt, P. K. . . 1965. California Med., 102, 171.

Dowd, J. M., Blink, D., Miller, C. H., 1966. J. Infect. Dis., 116, 473. Frank, P. F., and Pierce, W. E.

Eickhoff, T. C., AND Finland, M. . . 1965. New Engl. J. Med., 272, 395.

FALLON, R. J., AND Brown, W. . . . . 1966. Br. Med. J., 1, 1598.

Farrell, D. G., AND Dahl, E. V. . . . 1966. J. Amer. Med. Assoc., 198, 1189.

Feldman, H. A. . . . . . . . . . . 1965. Br. Med. J., 1, 436.

FLOREY, M. ETHEL . . . . . . . 1957. The clinical application of antibiotics 3, Chloramphenicol and the tetracyclines, Oxford, pp. 80-81.

Garrod, L. P., AND O'Grady, F. . 1968. Antibiotic and chemotherapy, Edinburgh and London, pp. 258 and 315.

Gauld, J. R., Nitz, R. E., Hunter, D. H. 1965. Amer. J. Epidem., 82, 56.

Rust, J. H., AND GAULD, R. L.

IVler, D., LeEdom, J. M., MAthies, A. W., JR, Fremont, J. C., Thrupp, L. D., PortNoy, B., AND WeHrLe, P. F.

LEEDOM, J. M., IVLER, D., MATHIES, A. W., Thrupp, L. D., PORTNOY, B., AND WEHRLE, P. F.

1965. In Antimicrobial agents and chemotherapy, 1964, ed. by Gladys L. Hobby, Ann Arbor, p. 358.

1965. New Engl. J. Med., 273, 1395. 
McKenzie, P., Love, W. C., Lawson, 1967. Postgrad. Med. J., 43, Suppl. on cephaJ. H., Pinkerton, I. W., Jamieson, W. M., AND STEVENSON, J.

Mathies, A. W., JR, Leedom, J. M., 1965. In Antimicrobial agents and chemoThrupp, L. D., IVler, D., Portnoy, B., AND WEHRLE, P. F. therapy, 1964, ed. by Gladys L. Hobby, Ann Arbor, p. 610.

Millar, J. W., Siess, E. E., Feldman, 1963. J. Amer. Med. Assoc., 186, 139. H. A., Silverman, C., and Frank, P.

TARr, H. A. . . . . . . . . 1958. Mon. Bull. Minist. Hlth, 17, 64.

Wiggins, G. L., and Schubert, J. H. . 1967. Bact. Proc., p. 96. 